dr hab. Joanna Kulczycka*

\title{
WSKAŹNIKI GOSPODARKI O OBIEGU ZAMKNIĘTYM DLA UNII EUROPEJSKIEJ I POLSKI
}

\author{
CIRCULAR ECONOMY IDICATORS FOR THE EUROPEAN UNION \\ AND POLAND
}

\begin{abstract}
The circular economy is one of the key elements of the European economic policy, aimed at rational use of resources and minimising the negative impact of product or process on the environment in the value chain. The results of these actions should maintain the value of products and materials for as long as possible and reduce waste and resource use. For this purpose, it is necessary to develop and select indicators for strategical actions in the field of circular economy. Therefore, the article reviews the proposed indicators and priority areas of the circular economy in the EU and selected countries, and assess the ranking of the Polish economy. The priority of circular economy tasks in Poland was the basis to propose important indicators for the assessment of transformation of Polish economy towards circular economy.
\end{abstract}

Keywords: circular economy, domestic material consumption, secondary raw materials

JEL classification: Q56, Q57, Q58

* Instytut Gospodarki Surowcami Mineralnymi i Energią Polskiej Akademii Nauk; kulczycka @)meeri.pl 


\section{Wprowadzenie}

Gospodarka o obiegu zamkniętym (GOZ; circular economy) stanowi jeden z priorytetów polityki gospodarczej Komisji Europejskiej w ostatnich latach. Jej zakres i zadania przedstawiono $\mathrm{w}$ dwóch dokumentach:

1) Komunikat KE, 2014: $\mathrm{Ku}$ gospodarce o obiegu zamkniętym: program „zero odpadów dla Europy”, KOM 398, w którym podkreślono, że przejście na GOZ wymaga zmian w każdym ogniwie łańcucha wartości, od fazy projektowania produktu, przez proces produkcji, konsumpcji, do nowych modeli biznesowych i rynkowych oraz zachowań konsumentów. Wymaga to zmiany systemowej oraz wdrażania innowacji nie tylko technologicznych, ale też organizacyjnych, oraz zmian w polityce gospodarczej i finansowej;

2) Komunikat KE, 2015: Zamknięcie obiegu - plan działania UE dotyczący gospodarki o obiegu zamkniętym, KOM 614, gdzie wskazano, że istotne jest utrzymanie wartości produktów, materiałów i zasobów w gospodarce tak długo, jak to możliwe, oraz minimalizowanie wytwarzania odpadów; zwrócono uwagę na trwałość produktów i ich ponowne użycie np. przez modernizację, naprawy oraz kaskadowe wykorzystanie. Jednocześnie podkreślono konieczność wzmocnienia i stosowania wielu istniejących metod, takich jak analiza przepływów materiałów (MFA) i ocena cyklu życia (LCA), a także systemów i narzędzi z zakresu np. zielonych zamówień publicznych (GPP), ekozarządzania i audytów (EMAS), weryfikacji technologii ochrony środowiska (ETV), rozszerzonej odpowiedzialności producent (EPR), najlepszych dostępnych technik (BREF) oraz ekoprojektowania.

Natomiast ocena wpływu GOZ na rozwój gospodarczy i propozycja jej monitorowania na poziomie UE zostały zaprezentowane w:

1) Komunikacie KE, 2018: w sprawie monitorowania gospodarki o obiegu zamkniętym, KOM 029, gdzie wyszczególniono cztery następujące grupy działań: (1) produkcja i konsumpcja, (2) gospodarowanie odpadami, (3) surowce wtórne, (4) konkurencyjność i innowacje, dla których zaproponowano 15 wskaźników. Jednocześnie podkreślono, że nie ma jednego powszechnie uznawanego wskaźnika „obiegu zamkniętego”, a działania i oceny w kierunku GOZ prowadzone w krajach członkowskich powinny być dostosowane do ich uwarunkowań społeczno-gospodarczych.

W związku z tym w wielu krajach UE, także w Polsce, prowadzone są działania zarówno na szczeblu krajowym (Ministerstwo Przedsiębiorczości i Technologii), jak i w niektórych regionach, które mają na celu ustalenie i opracowanie wskaźników transformacji w kierunku GOZ oraz wpływu GOZ na rozwój gospodarczy. Różne propozycje budowy wskaźników pojawiły się też w literaturze naukowej bądź zostały zgłoszone przez firmy konsultingowe i doradcze. Celem 
artykułu jest dokonanie przeglądu proponowanych wskaźników i priorytetowych obszarów GOZ w UE i niektórych krajach spoza UE oraz ustalenie pozycji Polski w wybranych obszarach GOZ. Na tej podstawie oraz uwzględniając specyficzne cele GOZ w Polsce wyszczególnione w krajowych dokumentach, m.in. w Mapie drogowej transformacji w kierunku GOZ, zaproponowano istotne wskaźniki służące do monitorowania transformacji gospodarki polskiej w kierunku GOZ.

\section{Propozycje wskaźników GOZ na poziomie UE - ich analiza i ocena}

Komisja Europejska zidentyfikowała dla całej UE sektory GOZ, dokonała ich oceny i zaproponowała wskaźniki monitorowania. Warto podkreślić, że w 2016 roku w sektorach istotnych dla GOZ zatrudniano ponad cztery miliony pracowników. Działania takie jak naprawa, ponowne użycie lub recykling wygenerowały niemal 147 mld EUR wartości dodanej, przyczyniając się do inwestycji wartych około 17,5 mld EUR, jednak materiały pochodzące z recyklingu zaspokajały niecałe $12 \%$ popytu na materiały w $\mathrm{UE}^{1}$. W celu monitorowania działań i efektów realizacji założeń GOZ oraz uwzględniając jej cel i zakres, KE zaproponowała - przypomnijmy - wskaźniki monitorowania GOZ ujęte w czterech następujących obszarach:

1) produkcja i konsumpcja;

2) gospodarowanie odpadami;

3) surowce wtórne;

4) konkurencyjność i innowacje.

Dla każdego z tych obszarów zaproponowano jeden lub kilka wskaźników, np. samowystarczalność UE w zakresie dostępu do surowców (w tym dla tzw. surowców krytycznych), udział zielonych zamówień publicznych, gospodarowanie odpadami, poziom recyklingu dla poszczególnych strumieni odpadów, wysokość inwestycji w działania i sektory GOZ czy liczba patentów związanych z gospodarowaniem i recyklingiem odpadami (rys. 1).

Zaproponowane wskaźniki zostały poddane merytorycznej dyskusji i opiniowaniu. Według Europejskiego Komitetu Ekonomiczno-Społecznego (Opinia w sprawie monitorowania gospodarki o obiegu zamkniętym 2018/C 367/19) Komunikat KE jest dobrym punktem wyjścia, brakuje jednak istotnych podstawowych wskaźników, tj. ekoprojektu, wzoru opracowywania (nowych) modeli biznesowych, gospodarki współpracy, wskaźników społecznych, danych dotyczących emisji. Ponadto GOZ powinien być powiązany z gospodarką niskoemisyjną

${ }^{1}$ Sprawozdanie Komisji dla Parlamentu Europejskiego, Rady, Europejskiego Komitetu Ekonomiczno-Społecznego i Komitetu Regionów z wdrażania planu działania dotyczacego gospodarki o obiegu zamkniętym, Bruksela 4.03.2019, COM(2019) 190 final. 


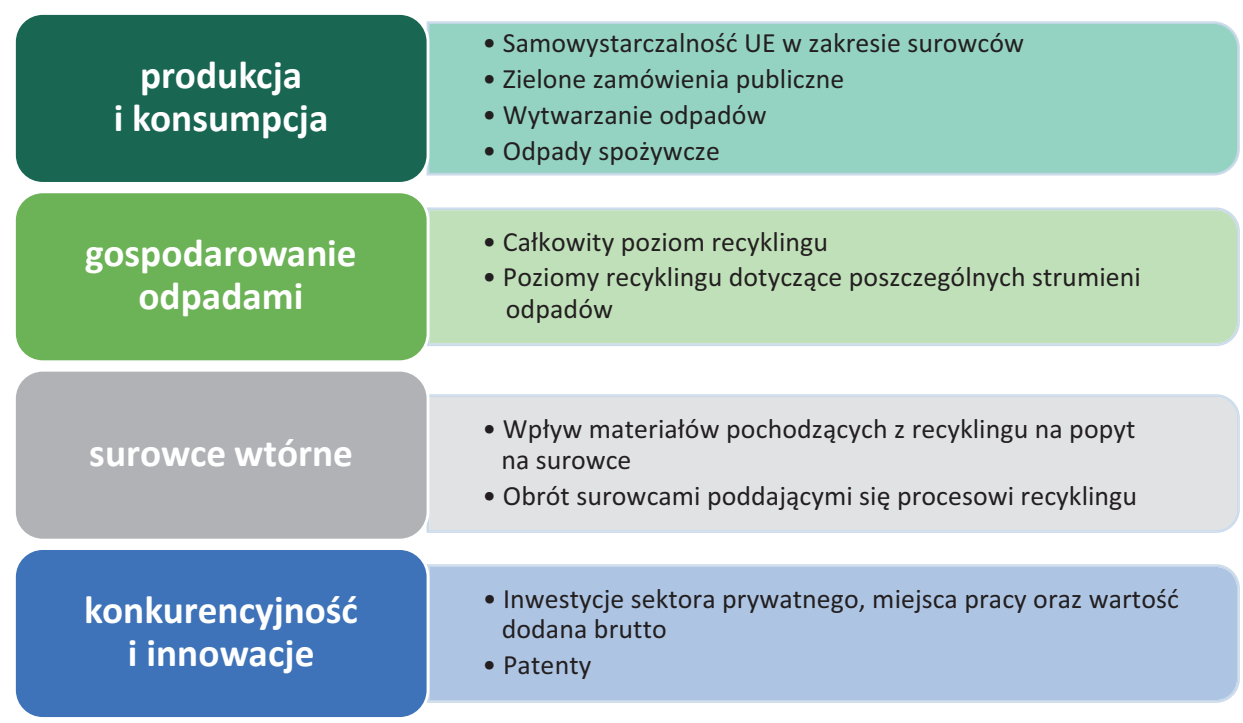

\section{Rysunek 1. Struktura wskaźników zaproponowana dla UE}

Źródło: opracowanie własne na podstawie Sprawozdanie Komisji dla Parlamentu Europejskiego, Rady, Europejskiego Komitetu Ekonomiczno-Społecznego i Komitetu Regionów z wdrażania planu działania dotyczacego gospodarki o obiegu zamkniętym, Bruksela 4.03.2019, COM(2019) 190 final.

i celami zrównoważonego rozwoju, co znalazłoby odzwierciedlenie we wskaźnikach monitorowania. Obecnie monitorowanie jest nadmiernie skoncentrowane na odpadach i należy je rozszerzyć na inne obszary. Ponadto definicja sektorów GOZ jest zbyt wąska, wymaga więc dopracowania. Występują również niespójności w zakresie polityki i przepisów, które utrudniają sektorowi przedsiębiorstw przestawienie się na model GOZ. Ważne jest, aby wykorzystanie pieniędzy publicznych było monitorowane za pomocą odrębnego wskaźnika. Należy też wprowadzić pomiar działań służących zwiększaniu świadomości i edukacji konsumentów i użytkowników o przepływach materiałów. Ogólnie rzecz ujmując, wskaźniki powinny z jednej strony mierzyć osiągnięte rezultaty i korzyści z GOZ, a z drugiej - badać stopień zamknięcia obiegu zasobów. Komisja zleciła także europejskim organizacjom normalizacyjnym opracowanie (do 2020 r.) horyzontalnych kryteriów pomiaru trwałości, zdatności do ponownego użycia, możliwości naprawy, możliwości poddania recyklingowi i obecności surowców krytycznych, utworzenie Europejskiego Centrum Wiedzy na temat Wydajności Zasobów, udoskonalenie oznakowania ekologicznego UE, rozpowszechnienie metodyki śladu środowiskowego PEF (przeprowadzona w ciągu ostatnich lat faza pilotażowa objęła analizą ok. 300 przedsiębiorstw 27 sektorów), wprowadzenie nowych i zmienionych kryteriów zielonych zamówień publicznych w UE, które będą uwzględniały zasady GOZ. 


\section{Polska na tle krajów UE w wybranych obszarach GOZ}

Z analizy proponowanych przez KE wskaźników wynika, że gospodarka Polski jest w pierwszej dziesiątce gospodarek UE uwzględniających wskaźniki dotyczące ilości wytwarzanych odpadów komunalnych per capita w UE (rys. 1), wskaźnik użycia materiałów w obiegu zamkniętym (Circular Material Use - CMU), który definiowany jest jako relacja ilości materiałów w obiegu zamkniętym do krajowej konsumpcji materialnej (Domestic Material Consumption - DMC) (rys. 2), wielkość inwestycji prywatnych w sektorze GOZ (rys. 3) czy liczbę miejsc pracy w tych sektorach w stosunku do miejsc pracy ogółem.

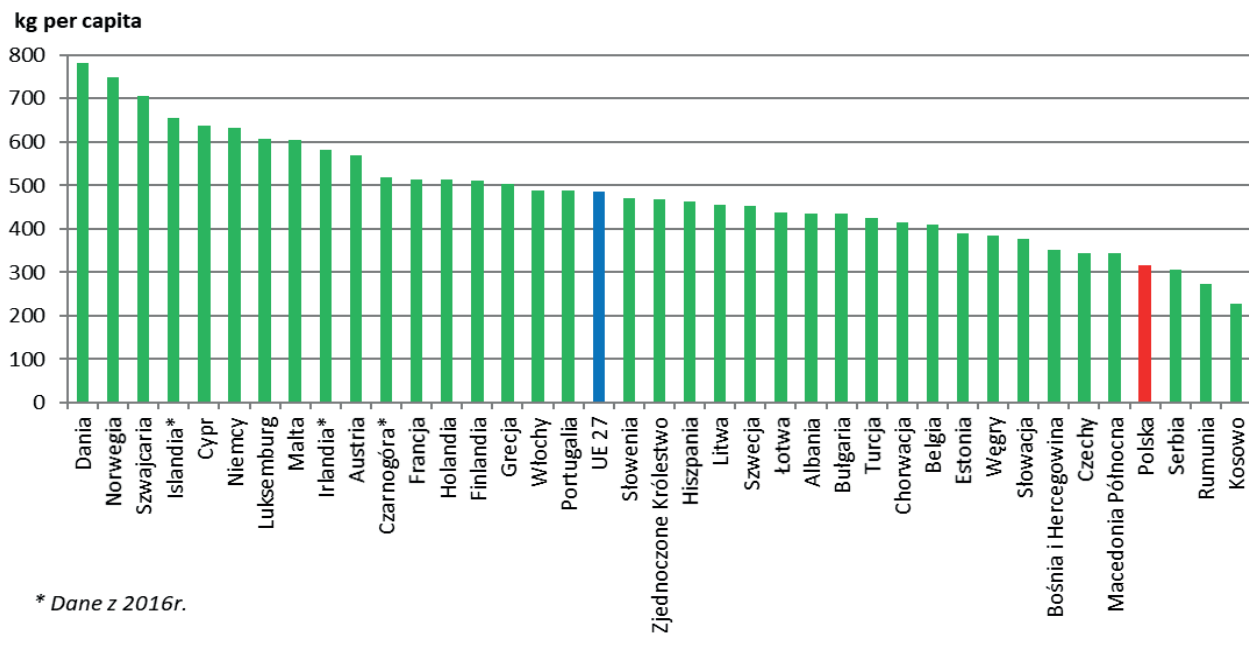

Rysunek 2. Wytwarzanie odpadów komunalnych w krajach UE w 2017 r. (kg per capita)

Źródło: opracowanie własne na podstawie bazy danych EUROSTAT.

Pozostałe wskaźniki - dotyczące poziomów recyklingu czy liczby patentów - są niekorzystne w porównaniu z innymi krajami UE. Z analizy tej jednoznacznie wynika, że wskazane jest poszukiwanie rozwiązań z zakresu zwiększania poziomów recyklingu, szczególnie w wypadku odpadów (opakowania, zużyty sprzęt elektryczny i elektroniczny). Takie działania wymagają nie tylko wspierania inwestycji, ale też zbudowania stabilnego systemu wspierającego recykling. Jedną $\mathrm{z}$ dobrych praktyk wprowadzonych $\mathrm{w}$ wielu krajach jest promowanie symbiozy gospodarczej, parków technologicznych, a ponadto kładzie się nacisk na opracowywanie skutecznych instrumentów ekonomicznych i prawnych np. w zakresie interpretacji produktu ubocznego, surowca wtórnego, złoża antropogenicznego ${ }^{2}$,

${ }^{2}$ E. Pietrzyk-Sokulska, B. Radwanek-Bąk, J. Kulczycka, Mineralne surowce wtórne - problemy polskiego nazewnictwa i klasyfikacji w związu z realizacja gospodarki o obiegu zamkniętym, „Przegląd Geologiczny” 2018, t. 66, nr 3, s. 160-165. 


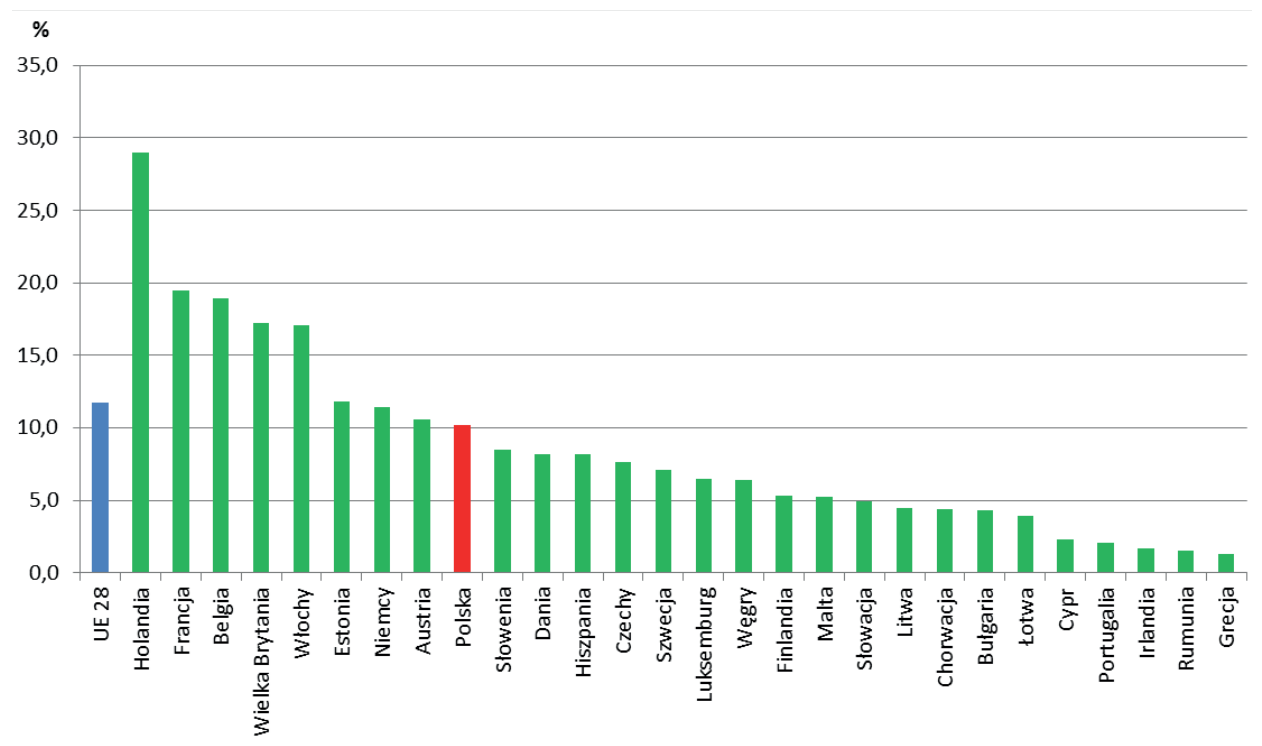

Rysunek 3. Wskaźnik zużycia materiałów w obiegu zamkniętym

Źródło: opracowanie własne na podstawie bazy danych EUROSTAT.

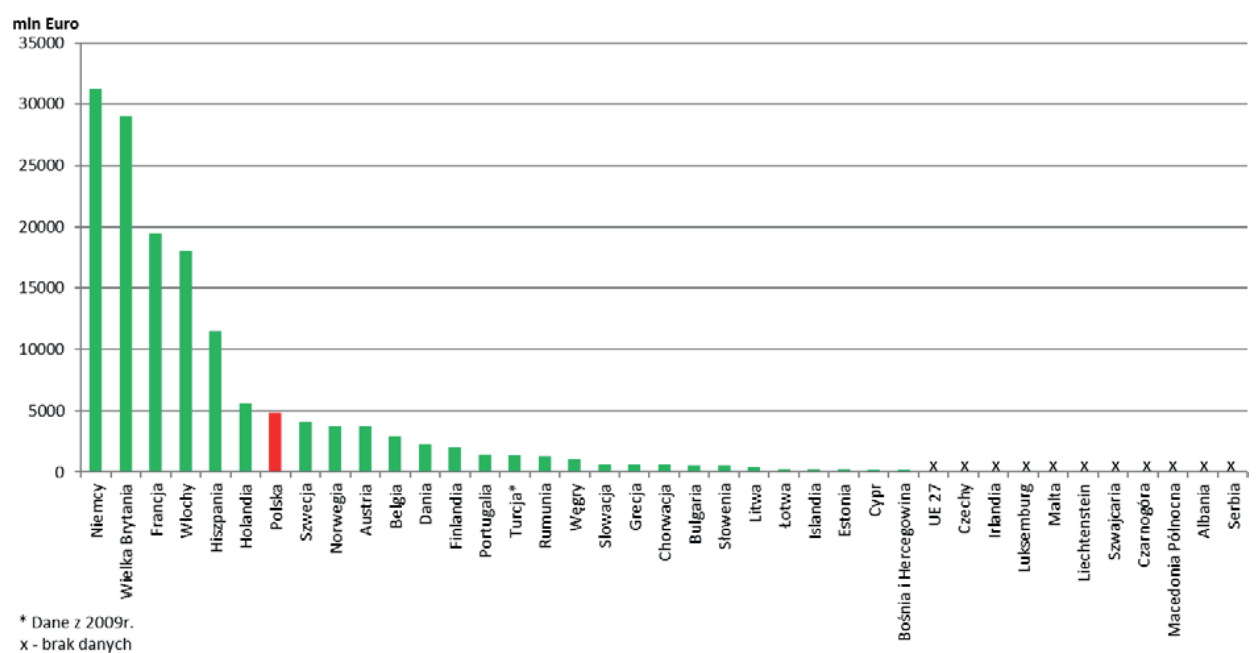

Rysunek 4. Wielkość inwestycji prywatnych w sektorze GOZ

Źródło: opracowanie własne na podstawie bazy danych EUROSTAT. 
na poszukiwanie rozwiązań technologicznych służących zagospodarowaniu generowanych odpadów ${ }^{3}$ itp. Zwiększenie wydatków na badania i innowacje $\mathrm{w}$ obszarze recyklingu (jedyny dedykowany tej branży program strategiczny w NCBiR „Innowacyjny recykling” został zawieszony po pierwszym konkursie) oraz promowanie rozwiązań organizacyjnych dotyczących napraw, ponownego użycia i regeneracji, a także wdrażanie nowych modeli biznesowych (np. ekonomia współdzielenia) czy instrumentów skierowanych na tworzenie całych łańcuchów wartości, w których odpady traktowane są jak zasoby, wydaje się koniecznością. Podkreśla się też znaczenie edukacji i promocji skierowanej zarówno do mieszkańców, jak i władz różnych szczebli oraz identyfikowanie i badanie potrzeb i poglądów mieszkańców w tym za$\mathrm{kresie}^{4}$. Największym jednak wyzwaniem będzie akceptacja i budowa modeli biznesowych GOZ przez przedsiębiorców, co wymagać będzie współpracy w łańcuchu wartości i tworzenia wspólnych działań - a dotychczas nie było to przedmiotem oceny.

\section{Wskaźniki dla gospodarki polskiej}

Realizacja i wdrażanie GOZ wymaga istotnej zmiany systemowej, która ma wpływ na całą gospodarkę i dotyczy wszystkich produktówi usług. W związ$\mathrm{ku} \mathrm{z}$ tym system monitorowania na poziomie kraju powinien uwzględniać zarówno ujęcie sektorowe, jak i regionalne. Punktem odniesienia dla monitorowania transformacji gospodarki w kierunku GOZ powinny być wskaźniki uwzględniające wielkość krajowej konsumpcji materialnej (DMC). Dotyczy to w szczególności wskaźnika materiałochłonności gospodarki oraz produktywności. Jest on obliczany dla kraju, ale przydatne byłoby również prowadzenie analiz dla poszczególnych działów produkcji oraz regionów. W relacji do innych krajów UE Polska niestety wykazuje bardzo wysoką materiałochłonność i niską produktywność zasobów (wskaźnik wyraża stosunek PKB do DMC - wysoka wartość produktywności zasobów świadczy o mniejszej ilości zużywanych zasobów naturalnych, a tym samym o mniejszym obciążeniu środowiska; tab. 1).

${ }^{3}$ A. Jarosiński, J. Kulczycka, Ocena możliwości pozyskiwania niektórych surowców krytycznych $w$ Polsce $w$ związu z realizacją koncepcji gospodarki o obiegu zamkniętym, „Inżynieria Mineralna" 2018, t. 19, nr 1, s. 315-324.

${ }^{4}$ J. Kulczycka, A. Nowaczek, M. Smol, A. Avdiushchenko, J. Hausner, Gospodarka o obiegu zamkniętym - znajomość i akceptacja założeń wśród mieszkańców Małopolski, „Aura” 2017, nr 10, s. 17-19. 
Tabela 1. Wybrane wskaźniki przepływów materiałów w gospodarce polskiej i UE

\begin{tabular}{|l|c|c|c|c|c|c|}
\hline \multicolumn{1}{|c|}{ Rok } & $\mathbf{2 0 1 1}$ & $\mathbf{2 0 1 2}$ & $\mathbf{2 0 1 3}$ & $\mathbf{2 0 1 4}$ & $\mathbf{2 0 1 5}$ & $\mathbf{2 0 1 6}$ \\
\hline DMC (tys. ton) & 797871 & 695354 & 657021 & 654385 & 643165 & 671921 \\
\hline Pozyskanie krajowe (tys. ton), w tym: & 745870 & 658159 & 635945 & 629889 & 627196 & 645432 \\
\hline Biomasa & 178562 & 172485 & 172727 & 188549 & 164948 & 184248 \\
\hline Rudy i metale & 25330 & 32511 & 32975 & 33320 & 33809 & 34156 \\
\hline Minerały niemetaliczne & 404924 & 309952 & 288963 & 271443 & 293623 & 293813 \\
\hline Energetyczne & 137054 & 142238 & 141280 & 136576 & 134816 & 133215 \\
\hline DMC tony per capita & 20,7 & 18,0 & 17,0 & 17,0 & 16,7 & 17,5 \\
\hline Produktywność UE (EUR/kg) & 1,79 & 1,97 & 2,03 & 2,07 & 2,16 & 2,19 \\
\hline Produktywność PL (EUR/kg) & 0,48 & 0,56 & 0,60 & 0,63 & 0,67 & 0,63 \\
\hline
\end{tabular}

Źródło: obliczenia własne na podstawie bazy danych GUS.

W krajach UE widoczny jest wyraźny wzrost wskaźnika produktywności, który w 2016 roku wyniósł 2,19 EUR/ $\mathrm{kg}^{5}$. Krajem o najwyższym wskaźniku produktywności zasobów w 2016 roku była Holandia (4,3 EUR/kg), natomiast najniższy wskaźnik wykazały Bułgaria i Rumunia - 0,3 EUR/kg.

W Polsce w latach 2008-2016 najniższą wartość wskaźnika produktywności odnotowano w 2011 roku i wyniosła ona 0,48 EUR/kg, z kolei najwyższa była w 2016 roku -0,67 EUR/kg, co wciąż wskazuje na niską produktywność zasobów. Wartość wskaźnika w 2011 roku wynika z bardzo wysokiego poziomu konsumpcji surowców niemetalicznych, głównie stosowanych do budowy m.in. dróg i autostrad, co było związane z intensyfikacją inwestycji prowadzonych na Euro 2012 i wydatkowaniem funduszy strukturalnych. Z kolei przewyższające wartości DMC w relacji do pozyskania krajowego rzędu $30 \mathrm{mln}$ ton wynikają z ujemnego salda handlowego i to głównie w grupie ,Surowce”, w której ramach w 2016 roku importowaliśmy $47,6 \mathrm{mln}$ ton $(27 \mathrm{mln}$ ton stanowiła ropa naftowa, a prawie $10 \mathrm{mln}$ rudy to koncentraty żelaza), a eksportowaliśmy $24,7 \mathrm{mln}$ ton, co może świadczyć o wciąż znaczącej zależności od importu surowców. Pozytywnym zjawiskiem jest dodatnie saldo handlowe w grupie „Produkty końcowe” (import 15,2 mln ton, a eksport 56,8 mln ton). Natomiast w grupie „Półprodukty” import to $8 \mathrm{mln}$ ton, a eksport wyniósł 25,2 mln ton.

Kolejnym ciekawym wskaźnikiem opartym na MFA, dotychczas nieanalizowanym i ważnym z punktu widzenia gospodarki polskiej, jest udział wielkości wytwarzanych odpadów ogółem (komunalnych i przemysłowych wraz z wydobywczymi) w relacji do DMC. Można go obliczyć dla krajów UE, jednak dane o odpadach wydobywczych zbierane są co dwa lata, zatem prezentowane w tabeli wartości obejmują lata 2012, 2014 i 2016. Im wyższy wskaźnik, tym większy udział odpadów, zatem z analizy wynika, że Polska jest znacznie powyżej średniej

\footnotetext{
${ }^{5}$ GUS, Rachunki Ekonomiczne Środowiska, Notka informacyjna, Warszawa 2018.
} 
UE, jednak wskaźnik dla naszego kraju jest korzystniejszy niż np. w Czechach, Słowacji czy na Węgrzech. Natomiast bardzo korzystne wartości można odnotować dla Bułgarii i Rumunii i stosunkowo mało korzystane dla Danii, Irlandii i Portugalii (tab. 2).

Tabela 2. Relacja DMC do ilości generowanych odpadów

\begin{tabular}{|c|c|c|c|}
\hline Kraje & 2012 & 2014 & 2016 \\
\hline EU-28 & 0,27 & 0,27 & 0,26 \\
\hline Austria & 0,34 & 0,28 & 0,27 \\
\hline Belgia & 0,29 & 0,25 & 0,23 \\
\hline Bułgaria & 0,08 & 0,08 & 0,11 \\
\hline Chorwacja & 1,19 & 1,04 & 0,80 \\
\hline Cypr & 0,89 & 0,6 & 0,54 \\
\hline Czechy & 0,68 & 0,69 & 0,65 \\
\hline Dania & 0,78 & 0,59 & 0,65 \\
\hline Estonia & 0,16 & 0,17 & 0,15 \\
\hline Finlandia & 0,2 & 0,18 & 0,14 \\
\hline Francja & 0,23 & 0,24 & 0,22 \\
\hline Grecja & 0,2 & 0,2 & 0,17 \\
\hline Hiszpania & 0,35 & 0,35 & 0,31 \\
\hline Holandia & 0,15 & 0,13 & 0,12 \\
\hline Irlandia & 0,71 & 0,63 & 0,68 \\
\hline Islandia & 25,96 & 16,46 & 14,52 \\
\hline Lichtenstein & 20,92 & 17,88 & 19,51 \\
\hline Litwa & 0,67 & 0,70 & 0,68 \\
\hline Luksemburg & 0,13 & 0,17 & 0,14 \\
\hline Łotwa & 1,00 & 0,91 & 0,90 \\
\hline Malta & 0,3 & 0,31 & 0,32 \\
\hline Niemcy & 0,36 & 0,35 & 0,32 \\
\hline Norwegia & 0,18 & 0,18 & 0,17 \\
\hline Polska & 0,43 & 0,37 & 0,37 \\
\hline Portugalia & 1,25 & 1,07 & 1,05 \\
\hline Rumunia & 0,14 & 0,21 & 0,25 \\
\hline Słowacja & 0,76 & 0,77 & 0,68 \\
\hline Słowenia & 0,56 & 0,58 & 0,48 \\
\hline Szwecja & 0,14 & 0,14 & 0,16 \\
\hline Węgry & 0,53 & 0,76 & 0,75 \\
\hline Wielka Brytania & 0,23 & 0,22 & 0,21 \\
\hline Włochy & 0,37 & 0,30 & 0,30 \\
\hline
\end{tabular}

Źródło: obliczenia własne na podstawie bazy danych Eurostat. 
Proponując wskaźniki dla Polski, powinno się również uwzględnić obszary priorytetowe, które zawarte są w Mapie drogowej transformacji w kierunku gospodarki o obiegu zamkniętym, opracowywanej w Ministerstwie Przedsiębiorczości i Technologii od 2016 roku, a obecnie przekazanej do rozpatrzenia przez Stały Komitet Rady Ministrów i skierowanej do dalszych prac legislacyjnych w postaci Projektu uchwały Rady Ministrów w sprawie przyjęcia Mapy drogowej transformacji w kierunku gospodarki o obiegu zamkniętym. Wyszczególniono w niej istotne obszary zawarte w kolejnych rozdziałach:

1) zrównoważona produkcja przemysłowa;

2) zrównoważona konsumpcja;

3) biogospodarka;

4) nowe modele biznesowe;

oraz propozycję wdrażania i monitorowania $\mathrm{GOZ}^{6}$.

W uzasadnieniu czytamy, że wzorem innych państw UE rząd polski zdecydował się opracować krajowy dokument implementujący koncepcję GOZ. Jest bowiem niezbędne, aby ten nowy model gospodarczy miał kompleksową i spójną podstawę oraz realizowany był na wszystkich szczeblach - począwszy od unijnego, przez państwa członkowskie, a skończywszy na regionach, województwach i gminach. Dokument ten zawiera propozycje działań na poziomie krajowym, które odpowiadałyby polskim uwarunkowaniom i specyfice naszej gospodarki ${ }^{7}$.

\section{Identyfikacja celów i działań GOZ w wybranych krajach czlonkowskich UE}

Analiza działań w zakresie wdrażania założeń GOZ na szczeblach rządowych w poszczególnych krajach członkowskich lub regionach wskazuje, że po 2014 roku oficjalnie zostały już przyjęte 33 dokumenty w 14 państwach. Strategie GOZ zakładają zazwyczaj koordynację działań, tak aby można było sprostać globalnym wyzwaniom i celom międzynarodowym, dotyczącym m.in. niedoboru zasobów, zmian klimatu oraz tworzenia globalnych łańcuchów wartości i realizacji polityki zrównoważonego rozwoju ONZ. Przykładowo:

- francuska strategia krajowa odnosi się do porozumienia paryskiego w sprawie zmian klimatu, koncentrując się na masowej mobilizacji konsumentów, obywateli, przedsiębiorstw i władz lokalnych w celu podjęcia działań na rzecz GOZ,

${ }^{6}$ Projekt Mapy drogowej transformacji w kierunku gospodarki o obiegu zamkniętym przestany na KRM, 2018, https://mpit.bip.gov.pl/fobjects/details/480822/pismo-przewodnie-pdf.html [dostęp: 13.05.2019].

${ }^{7}$ Projekt uchwały Rady Ministrów w sprawie przyjęcia Mapy drogowej transformacji w kierunku gospodarki o obiegu zamkniętym, 2018, https://bip.kprm.gov.pl/kpr/form/r62073261902,Projekt-uchwaly-Rady-Ministrow-w-sprawie-przyjecia-Mapy-drogowej-transformacji-w.html [dostęp: 13.05.2019]. 
- holenderska strategia krajowa odnosi się do dostępu do surowców - zakłada ograniczenie wykorzystania surowców pierwotnych o 50\% w 2030 roku dzięki współpracy z różnymi zainteresowanymi stronami,

- duńska strategia krajowa podkreśla konieczność równoważenia produkcji i konsumpcji, ma na celu wspieranie wzrostu gospodarczego i zatrudnienia, ale uwzględniając większą dbałość o zasoby naturalne w produkcji i konsumpcji,

- włoska strategia krajowa wskazuje na konieczność utrzymania pozycji kraju w produkcji w globalnych łańcuchach wartości przy ograniczeniu ryzyka wzrostu presji na środowisko,

- strategie dla Luksemburga i Niemiec postrzegają gospodarkę obiegową z perspektywy efektywnego gospodarowania zasobami i gospodarki odpadami ${ }^{8}$.

W większości dokumentów podkreśla się potrzebę lepszej znajomości tego problemu i prowadzenia badań w ujęciu wielosektorowym w łańcuchach wartości, wykraczającym poza zarządzanie odpadami i środowiskiem, a także budowania świadomości konsumentów w kierunku akceptacji GOZ. Niezbędne są zatem nowe regulacje prawne, np. zachęty finansowe promujące produkty z recyklingu (np. przez niższy podatek VAT), usługi (w tym naprawy) czy też współdzielenie (symbioza gospodarcza). Kluczowe znaczenie będzie miał system monitorowania i oceny realizacji strategii, jednak w większości tych dokumentów brakuje tego elementu lub jest on w fazie tworzenia.

\section{Podsumowanie}

Wdrażanie GOZ nie dotyczy tylko krajów UE, ta strategia została wprowadzona w Chinach już w 2002 roku i jest realizowana w wielu krajach na świecie. Wymaga ona znaczących zmian i nowych modeli biznesowych w obawie o brak dostępu do surowców, przed negatywnymi skutkami zmiany klimatu oraz innymi zagrożeniami dla środowiska. W najnowszym raporcie UNEP Global Resource Outlook 2019 analizowane są tendencje w skali globalnej, które zwracają uwagę na następujące fakty:

- Od 1970 roku wykorzystanie zasobów potroiło się, w tym nastąpił pięciokrotny wzrost zużycia surowców niemetalicznych i 45\% wzrost zużycia paliw kopalnych.

- Wydobycie i przeróbka surowców, paliw i żywności przyczynia się do połowy całkowitej emisji GHG i w 90\% wpływa na straty wody i bioróżnorodności.

${ }^{8}$ EESC, Circular Economy Strategies and Roadmaps in Europe, Identifying synergies and the potential for cooperation and alliance building Final Report. Study, 2019, s. 3-18, https://www. eesc.europa.eu/sites/default/files/files/qe-01-19-425-en-n.pdf [dostęp: 13.05.2019]. 
- W ciągu ostatnich 50 lat nastąpił dwukrotny wzrost liczby ludności, a PKB wzrósł czterokrotnie, natomiast roczne zużycie surowców to wzrost z poziomu 27 mld ton do 92 mld ton.

- Obecnie w krajach wysokorozwiniętych zużywamy średnio 9,8 ton surowców na osobę, a w UE 16 ton surowców na osobę rocznie, z czego 6 ton stanowią odpady, z których połowa trafia na składowiska.

Stwierdzono, że do 2060 roku całkowite zużycie surowców może się podwoić, osiągając poziom $190 \mathrm{mld}$ ton (obecnie $92 \mathrm{mld}$ ), powodując 43\% wzrost emisji gazów cieplarnianych.

Wprowadzenie GOZ jest zatem koniecznością, która powinna doprowadzić do całkowitej zmiany modelu gospodarowania. Będzie on miał wpływ na całą gospodarkę i powinien dotyczyć wszystkich produktów i usług. Pomimo iż monitorowanie GOZ jest trudne, musi być kompleksowe, a wskaźniki pomiarowe powinny odnosić się zarówno do oceny postępu transformacji w kierunku GOZ, jak i wpływu GOZ na rozwój społeczno-gospodarczy. Wskaźniki te należy opracowywać na poziomie mikroekonomicznym (podmiot ekonomiczny), mezoekonomicznym (regionalnym) lub makroekonomicznym (gospodarka narodowa). Bez wątpienia monitoring nie powinien dotyczyć tylko odpadów, a całych łańcuchów wartości i nowych modeli gospodarowania, stąd też podstawą monitorowania GOZ powinna być analiza przepływów materiałów i poziom ich konsumpcji. W Polsce w ramach Programu Strategicznego Gospostrateg takie zadanie jest realizowane przez konsorcjum MPiT, IGSMiE PAN, GUS i UEK, w projekcie „Opracowanie systemu wskaźników pomiarowych, umożliwiających ocenę postępu w transformacji w kierunku gospodarki o obiegu zamkniętym oraz wpływu gospodarki o obiegu zamkniętym na rozwój społeczno-gospodarczy na poziomie mezoekonomicznym (regionów) i makroekonomicznym (gospodarki narodowej)", który rozpoczął się w 2019 roku i będzie trwał do roku 2021.

\section{Bibliografia}

EESC, Circular Economy Strategies and Roadmaps in Europe, Identifying synergies and the potential for cooperation and alliance building Final Report. Study, 2019, s. 3-18, https://www.eesc. europa.eu/sites/default/files/files/qe-01-19-425-en-n.pdf [dostęp: 13.05.2019].

GUS, Rachunki Ekonomiczne Środowiska, Notka informacyjna, Warszawa 2018.

Jarosiński A., Kulczycka J., Ocena możliwości pozyskiwania niektórych surowców krytycznych $w$ Polsce $w$ zwiazku z realizacją koncepcji gospodarki o obiegu zamkniętym, „Inżynieria Mineralna" 2018, t. 19, nr 1, s. 315-324.

Kulczycka J., Nowaczek A., Smol M., Avdiushchenko A., Hausner J., Gospodarka o obiegu zamkniętym - znajomość i akceptacja założeń wśród mieszkańców Małopolski, „Aura” 2017, nr 10, s. 17-19.

Pietrzyk-Sokulska E., Radwanek-Bąk B., Kulczycka J., Mineralne surowce wtórne - problemy polskiego nazewnictwa i klasyfikacji w zwiazku z realizacja gospodarki o obiegu zamkniętym, „Przegląd Geologiczny” 2018, t. 66, nr 3, s. 160-165. 


\section{Dokumenty}

Komunikat KE, 2014: Ku gospodarce o obiegu zamkniętym: program „zero odpadów dla Europy”, KOM 398.

Komunikat KE, 2015: Zamknięcie obiegu - plan działania UE dotyczący gospodarki o obiegu zamkniętym, KOM 614.

Komunikat KE, 2018: w sprawie monitorowania gospodarki o obiegu zamkniętym, KOM 029.

Projekt Mapy drogowej transformacji w kierunku gospodarki o obiegu zamkniętym przesłany na $K R M$, 2018, https://mpit.bip.gov.pl/fobjects/details/480822/pismo-przewodnie-pdf.html [dostęp: 13.05.2019].

Projekt uchwały Rady Ministrów w sprawie przyjęcia Mapy drogowej transformacji w kierunku gospodarki o obiegu zamkniętym, 2018, https://bip.kprm.gov.pl/kpr/form/r62073261902,Projektuchwaly-Rady-Ministrow-w-sprawie-przyjecia-Mapy-drogowej-transformacji-w.html [dostęp: 13.05.2019].

Sprawozdanie Komisji dla Parlamentu Europejskiego, Rady, Europejskiego Komitetu Ekonomiczno-Społecznego i Komitetu Regionów z wdrażania planu działania dotyczącego gospodarki o obiegu zamkniętym, Bruksela 4.03.2019, COM(2019) 190 final.

\section{Streszczenie}

Gospodarka o obiegu zamkniętym jest jednym z kluczowych elementów europejskiej polityki gospodarczej, zmierzającej do racjonalnego wykorzystania zasobów i ograniczenia negatywnego oddziaływania produktów i procesów na środowisko w całym łańcuchu wartości. Efektem podejmowanych działań powinno być pozostawanie w gospodarce produktów, surowców i materiałów tak długo, jak to możliwe, a wytwarzanie odpadów powinno być w możliwie największym zakresie zredukowane. W tym celu konieczne jest właściwe opracowanie i dobranie wskaźników do strategii działania w zakresie GOZ. Stąd też celem artykułu jest dokonanie przeglądu proponowanych wskaźników i priorytetowych obszarów GOZ w UE i w wybranych krajach oraz zidentyfikowanie pozycji Polski w wybranych obszarach GOZ. Na tej podstawie oraz uwzględniając specyficzne cele GOZ w Polsce, wyszczególnione w krajowych dokumentach, zaproponowano wskaźniki istotne dla monitorowania transformacji gospodarki polskiej w kierunku GOZ.

Slowa kluczowe: gospodarka o obiegu zamkniętym, krajowa konsumpcja materialna, surowce wtórne

Numer klasyfikacji JEL: Q56, Q57, Q58 